Franco Pedrotti

\title{
The genus Cerastium (Caryophyllaceae) in the Stelvio National Park (Central Alps)
}

\begin{abstract}
Pedrotti, F.: The genus Cerastium (Caryophyllaceae) in the Stelvio National Park (Central Alps). — Fl. Medit. 25 (Special Issue): 257-261. 2015. — ISSN: 1120-4052 printed, 2240-4538 online.

This work presents the list of species of Cerastium L. (Caryophyllaceae) collected in the Stelvio National Park (the Ortles-Cevedale group in the central Alps) in the years from 1961 to 1970 by F. Pedrotti, E. Orsomando and C. Cortini Pedrotti (Camerino). A total of 9 entities were found and identified by W. Moeschl (Graz) $(\dagger)$; in addition, Cerastium holeosteoides from the Val di Sole (Trentino) is reported. The material collected was deposited in the Herbarium of the former Department of Botany and Ecology of the University of Camerino (CAME).

Key words: Cerastium, altitudinal distribution, vegetation belts, phytosociology.
\end{abstract}

\section{Introduction}

This work lists the nine entities of Cerastium L. (Caryophyllaceae) collected in the years between 1961 and 1970 in the Stelvio National Park, defined by its 1935 boundaries, which is in the Ortles-Cevedale group in the central Alps (leg. F. Pedrotti, E. Orsomando \& C. Cortini Pedrotti). The items collected were deposited in the Herbarium of the Department of Ecology and Botany of the University of Camerino (CAME).

All the exsiccata were determined by W. Moeschl (Graz) $(\dagger)$. A preliminary list of the species of the Cerastium L. genus in the Stelvio National Park was published by Pedrotti in 2005 .

\section{Material and methods}

For each taxon the following information is presented: nomenclature (Conti \& 2005), the chorological element (Aeschimann \& 2004), the minimum and maximum altitude at which the item was found, the altitudinal level(s) of reference, the type of vegetation in which the taxon was observed at the moment of collection and during the execution of the phytosociological relevés (Pedrotti \& al. 1974), and the name of the collection area. 
In addition, Cerastium holosteoides was collected in the Val di Sole (Trentino), in an area close to the Stelvio National Park; the exsiccatum of this finding (leg. F. Pedrotti; det. W. Moeschl) was also deposited in the University of Camerino Herbarium (CAME).

The names of the collection localities are reported as they appear on the herbarium labels; followed by the toponym, the name of the valley where the plant was found from Pedrotti \& al. (1974), in parenthesis to facilitate interpretation, with the lone exceptions of the cases in which the collecting locality in the label and the name of the valley in the I.G.M. maps coincide.

The locations are grouped with the following abbreviations: AA = Alto Adige (Sudtirol), TR $=$ Trentino.

\section{List of species}

Cerastium alpinum L. subsp. alpinum

Arctic-alpine; 2420-2580 m; alpine belt; various environments (moraines, soils rich in humus, etc.).

AA: morene Vedretta Saent (Val Martello), 2580 m, 26-VIII-1964.

TR: nei cirsieti (Peucedano-Cirsietum spinosissimi) presso il Rifugio Dorigoni (Rabbi), $2420 \mathrm{~m}, 3$-VIII-1964.

Note: this finding confirms its presence in Trentino.

C. arvense subsp. molle (Vill.) Arcang.

South-eastern European; 1550-2500 m; from the montane to the alpine belt; various environments (grazed alpine meadows, "campivoli" [grazing areas near mountain stalls], rocky environments, etc.).

AA: Solda di Fuori, 1550-1600 m, 25-VI-1965.

TR: sopra Malga Giumella (Peio), 1800 m, 21-VI-1965; parete rocciosa di Cima Vioz, 2500 m, 5-IX-1962; pendici occidentali Cima Vioz, nel Festucetum variae, 2400-2500 m, 5-IX-1962; Dente del Vioz, nel Festucetum variae, 2500 m, 5-IX-1962; sopra Peio, 1600-1650 m, 21-VI-1965; sopra Malga Stablazol (Rabbi), 1600 m, 20-VI-1965.

C. arvense subsp. strictum (W.D.J. Koch) Schinz \& R. Keller

Montane southern European; 1800-2600 m; from the high hilly to the alpine belt; various environments (grazed alpine meadows, grassy slopes, calcareous gravel screes, moraines, pebbly riverbanks); indicated in the JuniperoArctostaphyletum and Homogyno-Piceetum associations (Pedrotti 1966, 1980); C. arvense L. (s.l., without indication of subspecies), it is reported in the phytosociological tables for Cirsium patches (Peucedano-Cirsietum spinosissimi) at the Cevedale Refuge and below Le Lame (Val di Peio) (Pedrotti 1983).

AA: Solda, greto Rio Solda, 1850-1870 m, 20-VIII-1965; Val del Pozzo (Val Martello), 2350 m, 29-VIII-1964; Dosso Tabaretta, 2539 m, 11-VIII-1965; Malga Campo Piccolo (Trafoi), 2050 m, 23-VIII-1965; morene Vedretta Fine del Mondo, ghiaioni calcarei, 2340 m, 28-VIII-1965; stazione di arrivo della seggiovia Monte delle Vacche (Solda), nel Festucetum halleri, 2350 m, 28-VIII-1965; Monte Muta (Solda), vegetazione nitro- 
fila a Poa alpina, 2550-2570 m, 9-VIII-1965; imbocco Val Rosin (Val Martello), 1820 m, 2-IX-1964; ghiaioni calcarei fra Monte Marlet e Monte Muta, 2550 m, 9-VIII-1965; Solda, zone erbose vicino alla mugheta, $1900 \mathrm{~m}$, 5-VIII-1965; Solda, scarpate erbose, 1900 m, 6-VIII-1965; Dosso Glorenza, $2000 \mathrm{~m} \mathrm{ca}, 29-$ VI-1966; Val Martello, alla testata, 2200 m, 21-VIII-1964; lungo la strada dello Stelvio, 2000 m, 24-VI-1965; Val Peder (Val Martello), 2350-2400 m, 23-VIII-1964; sopra Rifugio Tabaretta (Solda), 2580 m, 8-VIII-1965; lungo strada dello Stelvio, $2000 \mathrm{~m}, 24-\mathrm{VI}-1965$.

TR: Pala della Donzella (Peio), 2600 m, 7-IX-1962; Saent (Rabbi), nello JuniperoArctostaphyletum, lungo il sentiero dal Rifugio Dorigoni a Casotto Saent (versante sinistro), 2300 m, 20-VIII-1963; Passo Cercena (Peio), 2600 m, 12-VIII-1962; Monte Vedretta Lamare, 2500-2600 m, 23-VIII-1962; Saentin (Rabbi), 2150 m, 13-VIII-1964; nel Peucedano-Cirsietum spinosissimi alla base delle morene Vedretta di Lamare, 2400 m ca, 22-VIII-1962; coste sopra Malga Pontevecchio (Val Lamare), nel Festucetum variae, $2325 \mathrm{~m}$, 12-VIII-1962; sopra Peio, 1600-1650 m, 21-VI-1965; sopra malga Stablasol (Rabbi), 1600-1650 m, 20-VI-1965.

C. cerastoides (L.) Britton

Arctic-alpine; 2436-2800 m; alpine belt; vegetation of the small nival valleys (Salicetalia herbaceae).

TR: Val Lamare, IX-1961; morene Vedretta Lamare, 2450-2500 m, 22-VIII-1962; Rifugio Dorigoni (Rabbi), 2436 m, 2-VIII-1962; costa sopra Lago Corvo (Rabbi), 2700-2800 m, 8-VIII-1964; Passo di Rabbi, 2480 m, 7-VIII-1964.

\section{C. fontanum Baumg.}

Arctic-alpine; 1880-2100 m; montane and subalpine belts; various environments (larch groves, peaty meadows, etc.).

AA: Paradiso del Cevedale (Val Martello), 2100 m, 26-VIII-1964; Solda, nel lariceto, 1880 m, 6-VIII-1965.

\section{C. glutinosum Fr.}

Mediterranean; up to $1600 \mathrm{~m}$; montane belt; steppe meadows (Festucetalia vallesiacae).

TR: Peio, nella vegetazione steppica, $1600 \mathrm{~m} \mathrm{ca}, 11-$ VIII-1962.

C. holosteoides Fr. [C. holosteoides subsp. triviale f. glandulosum (Boenn.) Möschl; C. fontanum subsp. vulgare (Hartm.) Greuter \& Burdet]

Eurasiatic which became cosmopolitan; 1600-2600 m; from the montane to the alpine belt; in alpine meadows (Arrhenatheretalia) and in the megaforbs communities (Adenostyletalia); previously reported (sub C. triviale) for the following locations: Dorigoni Refuge (Val di Rabbi), Vallombrina, under the Cevedale Refuge, Lago Lungo, Casotto del Careser (Val di Peio), where it grows in the Peucedano-Cirsietum spinosissimi association (Pedrotti, 1983).

AA: Sottostelvio (Trafoi), nel Rumicetum alpini, 2188 m, 27-VIII-1965; Tre Fontane Sante (Trafoi), $1600 \mathrm{~m} \mathrm{ca}, 29-\mathrm{VI}-1966$.

TR: presso Rifugio Cevedale, nel Festucetum halleri, 2550-2600 m, 26-VIII-1962; Peio nella vegetazione steppica, $1600 \mathrm{~m}$ ca, 11-VIII-1962; Val Maleda, 26-VIII-1963. 
In the Val di Sole (Trentino) C. holosteoides grows from 800 to $1650 \mathrm{~m}$ on mowable meadows throughout the valley where it is common in the meadow associations MelandrioArrhenatheretum and Trisetetum flavescentis (Arrhenatheretalia), Scirpetum sylvatici (Molinietalia) and Rumicetum alpini (Adenostyletalia); already reported (sub C. caespitosum) for the Val di Sole (Pedrotti 1963).

TR: Claiano, nei prati falciabili, $1000 \mathrm{~m} \mathrm{ca}, 30-\mathrm{VI}-1960$; Menas, nei prati falciabili, 1650 m, VI-1960; Dimaro, 800-850 m, VI-1960; Carciato, prati falciabili, $850 \mathrm{~m}$, 29-VI-1960.

\section{C. pedunculatum Gaudin}

Alpine; 2450-2900 m; alpine belt; pioneer vegetation of silicate substrata (Androsacetalia alpinae).

TR: morene Vedretta Lamare, 2450-2500 m, 22-VIII-1962; verso Passo Cavaion sopra bacino del Careser (Peio), 2800-2900 m, 11-IX-1962.

\section{C. uniflorum Clairv.}

Alpine-carpatic; 2100-3100 m; subalpine and alpine belts; pioneer vegetation of silicatic (Androsacetalia alpinae) and carbonatic (Thaspietalia rotundifolii) substrata.

AA: Val Martello, parete rocciosa sotto Rifugio Corsi, 2100-2220 m, 21-VIII-1964; verso Passo di Saent (Val Martello), 3000 m, 26-VIII-1964; Rifugio Tabaretta (Solda), 2555 m, 8-VIII-1965; Val Peder (Val Martello), 2780 m, 23-VIII-1964; ghiaioni calcarei fra Monte Muta e Monte Marlet, 2550 m, 9-VIII-1965; morene Vedretta Marlet (Solda), 2350 m, 8-VIII-1965; Passo Madriccio (Solda), 3124 m, 28-VIII-1964; Val Madriccio (Val Martello), 28-VIII-1964; morene Vedretta Saent (Val Martello), 2580 m, 26-VIII1964; Dosso Tabaretta (Solda), 2539 m, 11-VIII-1965; sotto Rifugio Tabaretta (Solda), 8-VIII-1965; verso Passo del Coston (Solda), $2600 \mathrm{~m} \mathrm{ca}, 26-$ VIII-1965; cresta sotto Rifugio Payer, 2900-3000 m, 10-VIII-1965.

TR: Vallombrina (Val del Monte, Peio), 2350-2400 m, 10-VIII-1962; La Valletta (Val del Monte, Peio), 2400-2500 m, 10-VIII-1962; Pala della Donzella (Peio), 2600 m, 7-IX1962; ghiaioni sopra Lago Corvo (Rabbi), $2900 \mathrm{~m} \mathrm{ca}$, 8-VIII-1964; verso Passo Cavaion, sopra bacino del Careser, 2800-2900 m, 11-IX-1962; Saentin (Rabbi), 2150 m, 13-VIII-1964; Dente del Vioz (Peio), 2850-2900 m, 4-IX-1962; Val Lamare, IX1961; Giogo Nero (Rabbi), 2833 m, 10-VIII-1964.

\section{Discussion}

The taxa of Cerastium were grouped according to the following altitudinal belts: from the high hilly to the montane ( $C$. glutinosum, $C$. holosteoides, $C$. arvense subsp. strictum, $C$. fontanum), from the montane to the subalpine ( $C$. arvense subsp. molle, $C$. fontanum, $C$. holosteoides) and from the subalpine to the alpine ( $C$. arvense subsp. strictum, $C$. arvense subsp. molle, C. uniflorum, C. alpinum subsp. alpinum, C. cerastoides, C. pedunculatum).

The taxa of the high hilly and montane belts are elements that gravitate in mediterranean environments (subpontic) and in montane western Europe, reaching the continent of Asia, while those of the subalpine and alpine belts are arctic-alpine or alpine elements. 
Concerning the environment and the vegetational types where they grow, the alpine and subalpine belts host a pioneer vegetation belonging to the Androsacetalia alpinae and Thlaspietalia rotundifolii (C. uniflorum, C. pedunculatum) orders, that of the small nival valleys (Salicetalia herbaceae) (C. cerastoides) and that of various environments (moraines, soils rich in humus, etc.) (C. alpinum subsp.a.). In the montane and subalpine belts, some species are of the mesophile meadows (Arrhenatheretalia and Nardetalia) and of the megaforbs communities (Adenostyletalia) such as $C$. holosteoides, others of steppe meadows (Festucetalia vallesiacae) like C. glutinosum. Finally, a group of taxa grows in diversified environments such as alpine meadows, megaforbs communities, grassy slopes, gravel screes, moraines, pebbly riverbanks, larch groves, open spruce woods and Swiss stone pine stands (C. fontanum, C. arvense subsp. strictum, C. arvense subsp. molle).

\section{Acknowledgements}

My heartfelt thanks to W. Möschl (Graz) (†) for the identification of the entities of the Cerastium genus and to S. Ballelli and D. Lucarini (Camerino) for revising the manuscript.

\section{References}

Aeschimann, D., Lauber, K., Moser, D. M. \& Theurillat, J.-P. 2004: Flora Alpina. - Bologna.

Conti, F., Abbate, G., Alessandrini, A. \& Blasi, C. (eds.) 2005: An annotated checklist of the italian vascular flora. - Roma.

Pedrotti, F. 1963: I prati falciabili della Val di Sole (Trentino occidentale). - Studi Trent. Sc. Nat. 40(1): 3-122.

- 1966: Associazioni dei Vaccinio-Piceetea del Parco nazionale dello Stelvio. -Studi Trent. Sc. Nat. 42(2): 202-210.

- 1980: Guida all'escursione della Società Botanica Italiana in Val d'Adige e nel Parco Nazionale dello Stelvio (27-30 giugno 1980). - Camerino.

- 1983: Sur l'association Peucedano-Cirsietum spinosissimi des Alpes centrales. - Coll. Phytosoc. 12: $189-195$.

- 2005: Il genere Cerastium L. (Fam. Caryophyllaceae) nel Parco Nazionale dello Stelvio. - P. 184 in: Pedrotti F. - Pedrotti L. (eds.), Abstracts Stelvio Seventy Conference (8-11 September 2005 - Rabbi Valley, Trentino, Italy). Trento.

-, Orsomando, E. \& Cortini Pedrotti, C. 1974: Carta della vegetazione del Parco Nazionale dello Stelvio (Notizia esplicativa). - Bormio.

Address of the author:

Franco Pedrotti,

Università di Camerino, Via Pontoni 5 - I -62032 Camerino (MC). E-mail: fran-

co.pedrotti@unicam.it 
